small one, will consist of representatives of the Colonial Office, and members of the Trades Union Congress and of employers' organizations interested in Colonial affairs. The Colonial Office already has a labour adviser, and the new Committee will serve to strengthen this side of its work. It may be anticipated that as the various provisions of the Welfare and Development Act come more extensively in force, this Committee will grow in importance and its activities play a prominent part in the future of the British Colonial Empire.

A brief survey of Colonial Office activities during the past year was also given by Mr. Hall. Even under war-time conditions it has been possible to send officials of the Colonial Office overseas to examine problems on the spot. Lord Hailey is presiding over a committee examining post-war problems which are likely to arise. Many schemes, amounting to hundreds of thousands of pounds, submitted under the Welfare and Development Act, have been approved. The appointment of an economic and financial adviser to work with Sir Frank Stockdale is being considered. The needs of Colonial peoples in Great Britain have also been examined; a welfare officer and an assistant welfare officer, the latter an African, have been appointed, and an adviser to Colonial students, who is a West Indian, is being appointed. Mr. Hall concluded by emphasizing that our duty is now to improve the lot of the Colonial peoples, to develop their resources so as to raise their standard of living, and to enable them to take an ever-increasing responsibility in their own government.

\section{Federation of American Societies for Experimental Biology}

Is March 1942 the Federation of American Societies for Experimental Biology will issue the first number of a quarterly publication to be named the Federation Proceedings. This will be published by an editorial board representing the five constituent societies of the Federation : the American Physiological Society, the American Society of Biological Chemists, the American Society for Pharmacology and Experimental Therapeutics, the American Society for Experimental Pathology, and the American Institute of Nutrition. Four numbers will be published each year. The March issue will appear just previous to the annual meeting of the Federation, and will be composed of two parts. Part 1 will include the abstracts of all the papers to be presented at the annual meeting, about a thousand in all. Part 2 will comprise the programme of the scientific sessions of all the constituent societies of the Federation. The June and September issues will include the full text of perhaps twenty of the papers presented at the annual meeting as selected by the editorial board, including probably the papers on the joint programme of the Federation as a whole as well as the papers of one symposium of each of the five societies. The December issue will include material pertinent to the Federation membership formerly published in the Federation Yearbook, which will hereafter be discontinued. The Federation Proceedings will be distributed without further charge to all members of the Federation. The subscription price to non-members will be four dollars (4.50 dollars foreign) payable in advance. Further information can be obtained from Dr. D. R. Hooker, Managing Editor, 19 West Chase Street, Baltimore, Maryland.

\section{Therapeutic Research Corporation}

A NEW step in the rationalization of the British fine chemical industry has been taken by the formation of the Therapeutic Research Corporation of Great Britain, Ltd., the directors of which are Lord Trent, of Boots Pure Drug Company, Ltd., Mr. C. A. Hill, of the British Drug Houses, Ltd., Mr. H. Jephcott, of Glaxo Laboratories, Ltd., Mr. T. B. Maxwell, of May and Baker, Ltd., and Mr. T. R. G. Bennett, of the Wellcome Foundation, Ltd. Although each of the directors of the new Corporation is managing director of his own concern, the Corporation is not an amalgamation of these five firms. Each will retain its freedom of action in its special field, but will contribute to the common research pool ; in effect, a much extended research team now becomes available for work on new drugs, and overlapping effort should be eliminated. It is also hoped to secure the interest and co-operation of research workers in academic institutions. The Corporation will have in the various chemical, physiological and bacteriological laboratories at its command the choice of many differęnt lines of approach to its problems and the call on the extensive scientific personnel and equip. ment of the five companies which are collaborating. This should make for a hopeful start and lay the foundation of a promising superstructure.

\section{Norway: Present and Future}

Mr. GATHORNE-HARDY's pamphlet. "Norway and the War" (Oxford Pamphlets on World Affairs, No. 51. 4d. net) gives an account of the physical characteristics and resources of Norway, its people and their democracy, and relations with their Scandinavian neighbours and other powers, which could scarcely be bettered as a contribution to the understanding of the Norwegian resistance to Nazism and of Norway's future. Although little more than a third of the pamphlet deals with Norway and the War proper, the pamphlet contains nothing irrelevant, and it emphasizes the close ties between Norway and Great Britain through the marked similarity of outlook, the ties of the sea, and the long association of various kinds.

Despite the appeal of Germany in scientific and technical circles, Norwegian thought, with its passionate insistence on individual liberty, free speech and parliamentary democracy, is diametrically opposed to the totalitarian ideology, and her neutrality had no spiritual basis. Mr. GathorneHardy emphasizes the important part which confusion, rather than deliberate treachery, played in the situation when Norway was invaded, and also the credit due to the Norwegians for the toughness of their resistance in a singularly desperate situation. After a brief account of the German occupation, he 